\title{
PENDAMPINGAN PEMANFAATAN LIMBAH PLASTIK ANORGANIK MENJADI PRAKARYA YANG MEMILIKI NILAI JUAL
}

\section{ASSISTANCE OF INORGANIC PLASTIC WASTE UTILIZATION BEING SELLING VALUE PRODUCTS}

\author{
Winda Roselina Effendi \\ Ilmu Pemerintahan Fakultas Ilmu Sosial dan Ilmu Politik \\ Universitas Riau Kepulauan, Batam, Indonesia \\ winda.effendis@gmail.com
}

\begin{abstract}
Abstak
Perlindungan dan pengawetan alam harus dilakukan oleh semua individu hal ini dilakukan sebagai upaya mempertahankan kelestarian alam. Pada dasarnya alam yang bersifat memberi kehidupan akan terus memberi manfaat, namun, seiring berkembangnya jaman banyak sekali hal-hal yang mencemari alam. Banyaknya limbah plastik anorganik menjadi salah satu penyebab rusaknya alam. Upaya yang banyak dilakukan adalah dengan melakukan daur ulang sampah anorganik ini. Seperti yang dilakukan pada pengabdian masyarakat pada RW 10 di kelurahan Bukit Tempayan. Batu Aji. Batam. Pendampingan Pemanfaatan Limbah Plastik Anorganik Menjadi Prakarya Yang Memiliki Nilai Jual, ini dilakukan dalam upaya menambah pendapatan ibu-ibu rumah tangga dan meminimalisir limbah plastik anorganik sehingga dapat mengurangi kerusakan lingkungan. Disamping itu dengan memanfaatkan limbah plastik anorganik juga menjadi salah satu upaya kreatifitas. Pada pendampingan ini limbah plastik didaur ulang menjadi tas, tempat pensil, dompet dan bunga.
\end{abstract}

Kata Kunci : Pemanfaatan, Limbah Anorganik, Kerusakan Lingkungan

\begin{abstract}
Abstrac
Nature protection and preservation must be done by all people. It is oe of efforts to maintain the nature preservation. Basically, nature gives life and always be, but due to the modernization era, there are a lot of things pollute nature. The amount of inorganic plastic waste becomes as one of nature destruction. Many efforts has been done, such as recycling inorganic waste, as a community service program which has been done at $r w 10$ at bukit tempayan,. Batu aji district. Batam. Assistance of inorganic plastic waste utilization being selling value products program was done as an effort to increase society's income and to minimize inorganic plastic waste, so it could reduce environmental damage. Beside it, by utilizing inorganic plastic waste, it became as one of creativity effort. In this assistance, plastic waste could be recycled into bags, pencils, wallets and flowers.
\end{abstract}

Keywords: Utilization, Inorganic Waste, Environmental Damage

\section{PENDAHULUAN}

Indonesia sebagai negara berkembang tidak luput dengan adanya permasalahan perkotaan. Sampai saat ini kondisi kota akan menjadi masalah akibat adanya degradasi 
lingkungan seperti adanya pemukiman kumuh, sanitasi yang kurang baik, permasalahan perlakuan terhadap sampah, industrialisasi penyebab limbah dan lainnya. Kota-kota besar di Indonesia saat ini telah mengembangkan diri untuk lebih ramah terhadap lingkungan serta berupaya untuk menjaga keberlanjutan lingkungan (Laila. 2014). Aksi kolektif yang dibangun oleh masyarakat mulai menunjukkan perubahan sikap terhadap penyelesaian problem lingkungan yang dimulai dari skala individu.

Kota menjadi daya tarik tersendiri bagi masyarakat, berbagai kebutuhan mulai dari fasilitas umum, pelayanan kesehatan, pekerjaan yang menjanjikan, pendidikan serta pertumbuhan ekonomi yang stabil tersedia di kota. Sehingga, peningkatan jumlah penduduk di perkotaan mencerminkan kecenderungan yang terus meningkat. Disatu sisi, kerusakan lingkungan akibat ulah manusia terjadi salah satunya karena tuntutan hidup mereka. Rendahnya pengetahuan, faktor pendidikan terbatas, serta pemenuhan kebutuhan sehari-hari yang kurang memadai membuat masyarakat miskin utamanya hanya berusaha mempertaankan hidup tanpa ada terlintas tentang kelestarian lingkungan. Di sisi lain, dengan bertambahnya arus urbanisasi yang tinggi kemudian dibarengi dengan terjadinya kecenderungan meningkatnya pembangunan industri baru menyebabkan bertambahnya beban bagi lingkungan.

Kepadatan penduduk yang terus meningkat utamanya di wilayah perkotaan akan mempengaruhi kualitas kota yaitu pada penghasil limbah serta pencemaran lingkungan akibat ulah mereka. Hal ini karena pola hidup mereka cenderung tidak memperhatikan dampak terhadap lingkungan yang kemudian akan mengancam kesehatan masyarakat serta keberlanjutan lingkungan itu sendiri. Dalam hal ini muncul inisiatif komunitas dalam suatu masyarakat untuk memperbaiki kualitas lingkungannya mulai dari perubahan gaya hidup bersih, penghijauan kampung, pemilahan sampah, penghematan penggunaan air, dan lainnya melalui aksi kolektif mereka. Untuk itu tulisan ini penting dalam mengkaji gerakan yang dilakukan masyarakat untuk melestarikan lingkungan tinggalnya yang akan mempengaruhi keberlanjutan lingkungan kotanya.

Alam pada dasarnya mempunyai sifat yang beraneka ragam, namun serasi dan seimbang. Oleh karena itu, perlindungan dan pengawetan alam harus terus dilakukan untuk mempertahankan keserasian dan keseimbangan itu. Sumber daya alam adalah untuk semua, makhluk hidup, bukan hanya untuk manusia (Hendawati, 2012). Oleh karena itu, manusia perlu mengadakan usaha-usaha untuk melestarikan lingkungan agar tetap serasi dan 
seimbang. Agar usaha-usaha tersebut dapat terlaksana, maka perlu diadakan kebijaksanaan di bidang pengelolaan sumber daya alam, yang mencakup pengelolaan. 1. Sumber Daya Mineral 2. Sumber Daya Tanah dan Air 3. Sumber Daya Hutan dan Tumbuh-tumbuhan 4. Sumber Daya Air dan Lautan Pelaksanaan pembangunan sebagai kegiatan yang makin meningkat resiko pencemaran dan perusakan lingkungan, sehingga struktur dan fungsi dasar ekosistem yang menjadi penunjang kehidupan dapat pula rusak karenanya. Terpeliharanya ekosistem yang baik dan sehat merupakan tanggung jawab yang menuntut peran serta setiap anggota masyarakat untuk meningkatkan daya dukung lingkungan (Manik. 2007).

Kota Batam merupakan salah satu kota dengan jumlah penduduk yang padat di Kepulauan Riau. Secara geografis, Kota Batam memiliki posisi yang strategis berbatasan langsung dengan Singapura dan Malaysia, sehingga menjadikan Kota Batam sebagai salah satu pusat perekonomian di Propinsi kepulauan Riau dan menjadi kawasan industri terbesar di Indonesia. Sebagai daerah industri, Kota Batam menarik minat para pendatang untuk mengadu nasib. Penduduk Kota Batam mengalami pertumbuhan penduduk yang cukup tinggi. Saat ini penduduk Kota Batam sudah mencapai 1.236.399 juta jiwa (BPS kepri,go.id tahun 2017). Semakin meningkatnya jumlah penduduk di Kota Batam berpengaruh terhadap kualitas lingkungan, seperti sampah, sanitasi dan drainase yang buruk, serta. Hal inilah yang menyebabkan sering terjadinya banjir di Kota Batam.

Terjadinya banjir juga disebabkan oleh sampah plastik yang tidak bisa melebur bersama tanah dan kurangnya kepedulian untuk membuang sampah pada tempatnya juga menjadi alasan.

Perumahan Sieera RW 10. Batu Aji merupakan wilayah yang berada di Kelurahan Bukit Tempayan yang sering mengalami banjir apabila turun hujan. Kondisi wilayah lingkungan yang berada pada turunan perbukitan menyebabkan lingkungan sering dilanda banjir apabila turun hujan, kurangnya pepohonan di lingkungan ini dan kurangnya drynase yang memadai juga menjadi salah satu penyebab banjir karena kurangnya daya serap. Selain itu, peran serta masyarakat rendah disebabkan oleh kurangnya perhatian masyarakat terhadap lingkungan. Ditambah lagi banyaknya sampah plastik anorganik dari limbah rumah tangga menambah faktor-faktor terjadinya banjir. Kesibukan warga RW 10 dalam memenuhi kebutuhan hidup mempengaruhi rendahnya peran serta masyarakat. Mayoritas masyarakat RW 10 berpendidikan SLTA dengan rata-rata bermata pencaharian buruh lepas dan pegawai swasta. Rata - rata warga di RW 10 memiliki pekerjaan atau usaha yang bisa memenuhi 
kehidupan sehari-hari. Namun, kesadaran untuk menjaga lingkungan masih rendah. Disamping itu kurangnya perhatian untuk menjaga lingkungan juga terjadi akibat bebas ekonomi yang sedang dihadapi sebagian besar buruh lepas dan swasta di kota Batam akibat banyaknya pemutusan hubungan kerja.

Dua faktor yaitu kurangnya menjaga lingkungan yang mengakibatkan banjir dan banyaknya pemutusan hubungan kerja tersebut, berangkat dari permasalahan yang ada, maka perlu dilakukan pengabdian masyarakat yaitu pemberdayaan masyarakat RW 10 dalam kegiatan pada kesempatan pengabdian masyarakat pada tanggal 19-20 Agustus 2017, dilakukan upaya Pendampingan Pemanfaatan Limbah Plastik Anorganik Menjadi Prakarya Yang Memiliki Nilai Jual, Pendampingan ini dilakukan sebagai upaya membantu mengurangi limbah plastik menjadi barang baru yang bernilai lebih, membantu mengurangi kerusakan lingkungan dan membantu mendapatkan nilai value sebagai pendapatan tambahan.

\section{METODOLOGI}

Pengabdian Masyarakat dalam kegiatan Pendampingan Pemanfaatan Limbah Plastik Anorganik Menjadi Prakarya Yang Memiliki Nilai Jual, dilaksanakan di RW 10 Kelurahan Bukit Tempayan, Kecamatan Batu Aji Kota Batam. Kegiatan ini dilakukan pada tanggal 1920 Agustus 2017, dengan melibatkan 26 mahasiswa.

Adapun metode yang digunakan dalam kegiatan ini adalah :

1. Pendekatan Persuasif

Pendekatan ini menitikberatkan kepada ide, sikap, dan usaha-usaha masyarakat atas dasar perubah kontak terarah dan selektif yang datangnya dari pihak luar sehingga menimbulkan motivasi, kreasi dan inovasi bagi masyarakat untuk mampu berfikir dan berbuat sesuai dengan kebenaran.

Pendekatan persuasif yang dilakukan terhadap masyarakat RW 10 Bukit Tempayan diawali dengan pertemuan pertama dengan warga melalui komunikasi terbuka dengan tokoh tokoh masyarakat yang cukup berpengaruh dilingkungan, dikesempatan ini Warga memberikan gambaran budaya dan kebiasaan warga RW 10 kemudian menyaring dan mencoba mengeluarkan ide program untuk memberdayakan lingkungan di RW 10, selain itu juga memberikan masukan dan saran apa-apa saja yang harus dibenahi dilingkungan RW 10.

2. Pendekatan Empirik, Normatik dan Edukatif 
Yaitu kepedulian terhadap norma-norma yang berlaku baik norma tersirat maupun tersurat di masyarakat.

Pendekatan Empirik dilakukan dengan peninjauan terhadap kebiasaan masyarakat langsung kelapangan dan juga memulai membuka komunikasi terhadap warga dengan membuka sesi tanya jawab sehingga mengetahui secara langsung masalah yang terjadi dimasyarakat Perumahan Sieera RW 10 Bukit Tempayan Kecamatan Batu Aji yaitu mengenai banyaknya limbah plastik anorganik dan pemutusan hubungan kerja.

Pendekatan Normatik yang dilakukan dengan memberikan penjelasan kepada masyarakat RW 10 mengenai solusi dari permasalahan dalam menanggulangi banyaknya limbah plastik anorganik dan pemutusan hubungan kerja adalah melakukan kegiatan pendampingan pemanfaatan limbah plastik anorganik menjadi prakarya yang memiliki nilai jual.

Pendekatan Edukatif yang dilakukan yaitu memberikan pengetahuan dan pemahaman kepada masyarakat RW 10 mengenai besarnya manfaat pendampingan pemanfaatan limbah plastik anorganik menjadi prakarya yang memiliki nilai jual dalam menjaga kualitas lingkungan dan memberi nilai ekonomis guna menambah pendapatan.

3. Pendekatan Andragogi

Yaitu sistem pembelajaran dengan prinsip partisipasi dan seni untuk membantu masyarakat belajar dan membelajarkan.

Pendekatan ini membantu untuk meningkatkan peran serta masyarakat dalam kegiatan pendampingan pemanfaatan limbah plastik anorganik menjadi prakarya yang memiliki nilai jual di wilayah tersebut. Pendekatan ini juga dpaat meningkatkan kesadaran masyarakat terhadap lingkungan dan kreatif dalam memanfaatkan limbah plastik anorganik.

\section{PEMBAHASAN}

Kegiatan pengabdian masyarakat melalui program pemberdayaan masyarakat RW 10 dalam pendampingan pemanfaatan limbah plastik anorganik menjadi prakarya yang memiliki nilai jual di Perumahan Sieera Kelurahan Bukit Tempayan ini memberikan pendekatan dan penawaran kepada masyarakat RW untuk menyelesaiakan permasalahan di RW 10. Solusi yang diberikan adalah melakukan kegiatan pendampingan pemanfaatan limbah plastik di RW 10 dalam menjaga kualitas lingkungan dengan melakukan mendaur ulang limban anorganik 
menjadi prakarya yang bertujuan untuk mengurangi sampah serta membantu warga agar lebih kreatif dan mandiri. Kegiatan pengabdian ini dilakukan 2 hari, yaitu tanggal 19-20 Agustus 2017.

Prosedur penyelesaian permasalahan yang dilakukan secara umum antara lain sebagai berikut Mengadakan pertemuan dengan perangkat RW dan RT serta masyarakat setempat guna membahas kegiatan pendampingan pemanfaatan limbah sampah anorganik, serta memberikan pengetahuan dan pemahaman mengenai pentingnya menjaga lingkungan dan mandiri secara kreatifitas serta manfaat dari pengolahan plastik menjadi prakarya. Pertemuan ini sudah dilakukan seminggu sebelumnya.

Melakukan observasi di lingkungan RW 10 guna menentukan tempat pendampingan dan pengumpulan limbah plastik. Bersama dengan masyarakat RW 10 menentukan jenis limbah plastik yang sesuai dengan bentuk prakarya yang ingin dirangkai. Memberikan hibah dana yang di pergunakan untuk alat, serta kebutuhan pendampingan yang akan dilakukan selama dua hari RW 10 tepatnya pada pendopo posyandu.

Kegiatan pendampingan pemanfaatan limbah plastik anorganik menjadi prakarya yang memiliki nilai jual diikuti oleh masyarakat RW 10, tepatnya ibu-ibu RW 10 dan kader posyandu RW 10 yang antusias ikut dalam kegiatan pemanfaatan limbah plastik tersebut. Setelah kegiatan pendampingan pemanfaatan limbah plastik anorganik selesai dilakukan, selanjutnya dilakukan kegiatan gotong royong untuk membersihan selokan sepanjang Perumahan Sieera RW 10 yang dilakukan bersama-sama oleh masyarakat RW 10. Dalam kegiatan tersebut juga mengumpulkan limbah plastik rumah tangga, menyisihkan sampah plastik dan organik, mengubur sampah organik dan mencuci sampah plastic yang dibutuhkan sebagai bahan prakarya.

Pelaksanaan kegiatan pendampingan pemanfaatan limbah plastik melalui membuat prakarya yang punya nilai jual disertai gotong royong memberikan manfaat yang besar bagi lingkungan di RW 10, dimana setelah kegiatan tersebut selesai dilakukan lingkungan RW 10 terlihat lebih rapi dan bersih dan juga dengan diadakan pendampingan pemanfaatan limbah sampah anorganik menambah pengetahuan warga RW 10 terhadap kreatifitas yang dapat menambah pendapatan dan nilai guna terhadap limbah.

\section{KESIMPULAN}


Program Pendampingan Pemanfaatan Limbah Plastik Anorganik Menjadi Prakarya Yang Memiliki Nilai Jual dapat diselenggarakan dengan baik dan berjalan dengan lancar sesuai dengan rencana kegiatan yang telah disusun meskipun belum semua peserta pendampingan (ibu-ibu Perumahan Sierra RW 10) menguasai dengan baik materi dan praktik yang disampaikan. Kegiatan ini mendapat sambutan sangat baik terbukti dengan keaktifan peserta mengikuti pendampingan dengan tidak meninggalkan tempat sebelum waktu pelatihan berakhir.

Dari kegiatan pengabdian yang telah dilaksanakan, maka dapat disimpulkan bahwa:

1. Melalui pendekatan persuasif dapat meningkatkan peran serta masyarakat RW 10 dalam kegiatan pemanfaatan limbah plastik anorganik. Terlihat dari tingginya partisipasi masyarakat terutama ibu-ibu mulai dari kalangan tua sampai kalangan muda ikut dalam kegiatan pemanfaatan limbah plastik anorganik dan gotong royong.

2. Kegiatan pemanfaatan limbah plastik anorganik melalui pembuatan prakarya dapat meningkatkan kualitas lingkungan di RW 10 dan menciptakan kreatifitas serta menambah nilai ekonomis limbah sehingga dapat mencegah terjadinya banjir, serta membuat lingkungan RW 10 menjadi bersih dan kreatif.

3. Bentuk pemanfaatan limbah plastik anorganik seperti pembuatan prakarya perlu dukungan moral seluruh masyarakat, secara khusus masyarakat RW 10, dalam arti adanya rasa kepemilikan bersama untuk menjaga bersama kelestarian lingkungan dan alam.

\section{REFERENSI}

Dra. Yuyu Hendawati, M.Pd, 2012. Pelestarian Lingkungan dan Cara Pencegahan Kerusakanya Jakarta: Jurnal Linkungan Hidup vol 1.

Anita, Nur Laila. 2014, Gerakan Masyarakat Dalam Pelestarian Lingkungan Hidup (Studi Tentang Upaya Menciptakan Kampung Hijau Di Kelurahan Gundih Surabaya) : Jurnal Politik Muda, Vol. 3 No. 3.

ESP-USAID. 2010. Modul Pelatihan Pengelolaan Sampah Berbasis Masyarakat. Jakarta: Environmental Services Program.

Karden Edy Sontang Manik. 2007. Pengelolaan Lingkungan Hidup. Jakarta: Penerbit Djambatan 
Ni Komang Ayu Artiningsih. 2008. Peran Serta Masyarakat dalam Pengelolaan Sampah Rumah Tangga (Studi Kasus di Sampangan dan Jomblang, Kota Semarang). Tesis. Semarang: UNDIP.

Undang-Undang Republik Indonesia No. 18 Tahun 2008 tentang Pengelolaan Sampah.

Undang-Undang Republik Indonesia No. 33 Tahun 2012 tentang pengelolaan Sumber daya alam berbasis pemulihan lingkungan.

www.BPS kepri,go.id tahun 2017 